\title{
NEUVOSTOJÄRJESTELMÄN HAAKSIRIKKO JA SOSIALISMI
}

\author{
Jouko Kajanoja
}

VTT, Helsinki

Neuvostoliiton hajoamisen vuosina 19891991 olin töissä ja asuin Pietarissa. Toimin yhteisyrityksen varatoimitusjohtajana ja olin yrityksen ainoa ulkomaalainen. Ekonomina keskeinen tehtäväni oli opettaa henkilöstölle markkinointia, liiketaloudellisten tuottolaskelmien tekemistä ja muita markkinatalouden toimintatapoja. Se oli ironinen tehtävä Suomen Kommunistisen Puolueen entiselle puheenjohtajalle.

Sain Pietariin luettavakseni Suomen Moskovan-lähetystön ulkoministeriölle lähettämiä raportteja. Kun tapasin silloisen ulkoministeri Pertti Paasion, arvostelin hänelle raporttien pinnallisuutta. Niissä spekuloitiin Duuman voimasuhteita, kun mielestäni painopisteenä olisi pitänyt olla analyysi yhteiskunnan perusteita järisyttävästä murroksesta. Sovin Paasion kanssa, että teen aihepiiristä raportin. Luin asiaan liittyvää kirjallisuutta, jonka joukosta kiinnostavin oli Maailmanpankin tuottama perusteellinen arvio neuvostotaloudesta. Kävin Moskovassa haastattelemassa asiantuntijoita, erityisesti historioitsijoita. Pohjana olivat myös omat liike-elämän ja asukkaan kokemukseni Pietarissa ja 1980-luvulla käymäni keskustelut Neuvostoliiton kommunistisen puolueen keskuskomitean toimihenkilöiden ja neuvostotutkijoiden kanssa. Tuloksena oli vuonna 1991 julkaistu, valtiojohdolle tarkoitettu raportti "Tulevaisuudenkuva Neuvostoliitosta eli mitä sen tilalle on syntymässä: Raportti kauppa- ja teollisuusministeriön rahoittamasta tutkimuksesta.” Siitä otettiin pienehkö painos.

Raportin alussa esitin käsitykseni neuvostojärjestelmän romahduksen syistä. Keskeisim- pänä näin demokratian puutteen. Ylhäältä johdettu yhden puolueen valta esti kansalaistoiminnan. Keskitetty talousjohto ehkäisi tuotannollista aloitteellisuutta. Arvelin, että Leninin aikana käynnistetyn, yksityisyritteliäisyyttä suosineen NEP-politiikan tukahduttaminen ja maatalouden pakkokollektivisointi olivat johtaneet ylhäältä ohjattuun yhteiskuntamalliin. Se oli raskaan teollisuuden rakentamisen aikana melko tehokas, mutta monipuolisempi tuotanto vaatii joustavuutta ja tuotannossa toimivien aloitteellisuutta. Neuvostoliiton johdossa oli voimia, jotka olivat tästä tietoisia. Uudistajien aloitteesta NKP:n keskuskomitea hyväksyi 1960-luvun puolessa välissä koeäänestyksen jälkeen mallin, joka olisi siirtänyt tukkukaupan markkinapohjalle. Mallia ei pantu toimeen. Valta-asemansa menettämisestä huolestunut brežneviläinen puoluekoneisto ehkäisi uudistuksen toimeenpanon.

Maailmanpankin raporttien ja haastattelemieni tutkijoiden mukaan neuvostotalous menestyi melko hyvin ja kansan kulutustaso nousi. Lisäksi 1950-luvun lopulla ja 1960-luvulla vallinnut hruštševilainen vapautumisen ilmapiiri loi myönteistä tulevaisuuden uskoa kansan keskuudessa. Talouden kehitys alkoi kuitenkin takkuilla 1970-luvulta lähtien. Poliittinen paine johti tuotannon painopisteen siirtymiseen kulutustavarateollisuuden puolelle, ja välttämättömiä tuotannon rakenteellisia investointeja lyötiin laimin. Tuloksena oli taloudellisten tulevaisuusnäkymien synkkeneminen, eikä kulutustavaratuotantokaan ollut kehuttavaa. Hruštševilainen vapautumisen ilmapiiri alkoi vaihtua brežneviläiseen ahdasmielisyyteen. 
Gorbatšovilainen 1980-luvun uudelleen rakentaminen (perestroika) ja avoimuus (glasnost) tulivat liian myöhään. Ne avasivat ummehtuneen kattilan kannen, eikä kehitys enää pysynyt puolue- ja valtiojohdon hallinnassa. Puolue lakkautettiin, Neuvostoliitto hajosi, ja Venäjällä ja muissa neuvostotasavalloissa omaksuttiin siihen asti ehdottomasti torjuttu kapitalistinen talousjärjestelmä.

Pidin raportissani Maailmanpankin suosituksia perusteltuina. Yhteiskunta tarvitsi ripeästi uuden järjestelmän. Pahin vaihtoehto oli kaaoksen jatkuminen, joka johtaisi viidakon lakiin. Koin sen omassa työssäni pietarilaisessa yrityksessä. Hämärämiehiä kävi vaatimassa suojelurahaa.

Maailmanpankin arviot Neuvostoliiton/ Venäjän tulevaisuudesta olivat tavoitehakuisia. Arvioissa maalattiin ruusuinen talouskuva, mikäli valittaisiin ripeä tuotannon yksityistäminen. Ennusteet tuotannon yksityistämisen seurauksista olivat ylioptimistisia. Ennusteiden tekijät eivät varmaan itsekään uskoneet niihin. Ennusteiden tehtävänä oli houkutella venäläisiä valitsemaan kertarysäys kohti kapitalismia. Tein raportissani tulevaisuuslaskelmia, jotka olivat paljon pessimistisempiä. Ne osuivat karkeasti ottaen oikeaan.

Maailmanpankin linja oli siinä mielessä perusteltu, että se hahmotti nopeaa tietä pois kaaoksesta. Mutta linja oli sillä tavoin rujo, että se ei paljastanut tulevan kehityksen ongelmien syvyyttä. Olisi luultavasti ollut kaikkien kannalta parempi, jos järjestelmän muutosta olisi pehmitetty sosiaalipoliittisilla turvatoi- milla ja valtion omaisuuden yksityistämistä olisi hoidettu niin, ettei omaisuus olisi ajautunut suurelta osin häikäilemättömimpien oligarkkien käsiin.

Entä Neuvostoliiton haaksirikon vaikutus ymmärrykseen sosialismista? Kirjoitan omista ajatuksistani, joita en tohdi yleistää, mutta arvelen monen jakavan ne.

Näin kyllä ennen romahdusta neuvostojärjestelmän epäkohtia, mutta en oivaltanut sitä tuhoisuutta, joka piili keskitetyssä pakkoohjauksessa ja toisinajattelun torjunnassa. Ajattelin järjestelmän kykenevän korjaamaan itseään ja demokratisoitumaan, enkä ymmärtänyt brežneviläisen pysähtyneisyyden ja valtarakenteiden itsesuojelun syvyyttä.

Keskeinen muutos omassa ajattelussani oli etääntyminen "valtiokapitalismista". Aiemmin pidin joidenkin keskeisten tuotannon ja liike-elämän alojen valtiollistamista suotavana. Nyt en pidä sitä kovinkaan hyvänä ajatuksena. Luontaisesti monopolistisen tuotannon on syytä olla yhteiskunnan omistamaa, ja yhteiskunnallista omistusta tarvitaan uudenlaisen tuotannon kehittämiseen. Muutoin kannatan mieluummin vaikkapa osuuskuntia. Edelliseen liittyen ajatteluni lähtee nyt aiempaa voimakkaammin alhaalta lähtevästä hallinnasta ja kaikenlaisen alistamisen torjumisesta. Se on paluuta alkuperäiseen sosialismiin sellaisena kuin se ilmeni esimerkiksi Saksan sosialidemokraattisen puolueen vuoden 1892 Erfurtin ja Suomen sosialidemokraattisen puolueen vuoden 1903 Forssan ohjelman osuuskunta-ajattelussa ja käsityksissä tasa-arvon edistämisestä. 